\title{
О РОЛИ ВОЕННО-ПРОМЫШЛЕННОГО КОМПЛЕКСА В МИЛИТАРИЗАЦИИ СОВРЕМЕННОГО МИРОВОГО ХОЗЯЙСТВА
}

\author{
(c) 2020 Гилькова Ольга Николаевна \\ кандидат экономических наук, научный сотрудник, Центр международной безопасности \\ Национальный исследовательский институт мировой экономики \\ и международных отношений им. Е. М.Примакова РАН, Россия, Москва \\ E-mail: olga.gilkova@yandex.ru
}

В данной статье представлен анализ степени воздействия военно-промышленных комплексов ведущих стран мира на развитие милитаристских процессов в мировой экономике. Раскрыт механизм внутренних связей военно-промышленных комплексов этих стран на примере военнопромышленного комплекса США.

Ключевые слова: военно-промышленный комплекс (ВПК), милитаризация, гонка вооружений, военнопромышленная корпорация, лоббизм, «железный треугольник», «вращающиеся двери», «амакудари».

Милитаризация мирового хозяйства - одна из важнейших глобальных проблем XXI в. Раскрытие ее сущности служит трамплином к пониманию причин гонки ядерных и других видов вооружений, а также причин существования угрозы начала новой мировой войны.

В современных условиях основной силой, подстегивающей непрерывное расширение военных приготовлений и военно-технических программ, постоянное наращивание военной мощи, является военно-промышленный комплекс (ВПК). Это в известном смысле закономерно, ибо подготовка и ведение войн является материальной основой существования и обогащения ВПК.

ВПК представляет собой специфическое объединение предприятий (научно-исследовательских, испытательных и производственных), представителей вооруженных сил и правительства, занятых производством военной продукции и поддержанием военного сектора экономики.

Тесные связи военных промышленников с руководителями правительств, членами законодательных органов возникли еще в XIX в. В это время, например, в США была широко известна «пороховая империя» Дюпонов, имевшая тесные контакты как с руководителями правительства, так и с командованием армии и военно-морского флота, оказывая, таким образом, влияние на экономическую жизнь страны и на ее внешнюю политику. Однако в то время подобные связи имели временный, эпизодический характер, они еще не были достаточно прочны- ми и всеобъемлющими, а их влияние на общественную жизнь государств было весьма слабым.

Такого рода связи расширились и укрепились после Второй мировой войны, когда многие сравнительно небольшие предприятия, производившие самолеты, артиллерийские орудия, танки, превратились в огромные военнопромышленные монополии, оказывающие заметное влияние на экономику и политику. С тех пор ВПК стали набирать силу во всех ведущих государствах мира. Но в наиболее развитом виде ВПК сформировался в США в послевоенный период в разгар «холодной войны», когда правящие круги этой страны открыто взяли курс на мировую гегемонию, военная верхушка стала претендовать на особое место в американском обществе, а развитие науки и техники, приведшее к созданию ракетно-ядерного оружия, потребовало крупных преобразований в военном секторе экономики. Развитие государственномонополистических тенденций, передача многомиллиардных правительственных заказов на производство оружия в руки частных монополий - все это привело к образованию ВПК в его современном виде.

ВПК сегодня является реально существующей политической и экономической силой, что хорошо осознают руководители государств и другие политические деятели. Уходя с поста президента США, Д. Эйзенхауэр в январе 1961 г. обратился к американцам с прощальным посланием, в котором он, в частности, говорил: «...Это объединение колоссального военного аппарата и крупной военной промышленности - нечто 
новое в истории Америки. Его всеобъемлющее влияние - экономическое, политическое и даже духовное - ощущается в каждом городе, в органах управления каждого штата, в каждом учреждении федерального правительства...Мы должны в наших государственных делах остерегаться установления военно-промышленным комплексом ничем не оправданного влияния независимо от того, является оно преднамеренным или непреднамеренным. Потенциальная возможность пагубного усиления этой неправомерной власти существует и будет существовать» [4].

Фактически, ВПК представляет собой группировку государственных органов и частных организаций, а также официальных и неофициальных лиц, оказывающих решающее влияние на принятие решений в военной, военнополитической и военно-экономической областях во имя обеспечения как общих интересов, так и своих собственных узкокорыстных интересов. Арсенал методов и средств, применяемых ВПК для своих целей, исключительно широк: от освященных законом официальных и полуофициальных процедур до махинаций, подкупа и т.д.

В структуре ВПК, который иногда именуют «железным треугольником», достаточно четко вырисовываются три основные составные части: руководство военно-промышленных корпораций, военная верхушка и связанная с ними часть государственного аппарата. Это наиболее заметная и активная часть ВПК, действующая на авансцене политической жизни. За ее спиной стоит могущественная финансовая олигархия.

Политическое влияние ВПК в США и ряде других государств определяется, прежде всего, тем обстоятельством, что его деятельность, направленная на систематическое наращивание военной мощи, соответствует общестратегическим, экономическим и политическим интересам богатейших и влиятельнейших монополистических групп.

Так, в США в выполнении военных заказов участвует огромное количество различных по профилю фирм, но доминирующую роль в военном производстве играют крупные специализированные корпорации. Уровень концентрации и монополизации в военном производстве весьма высок. Современная американская военнопромышленная корпорация - это крупная фирма с несколькими отделениями, многочис- ленными производственными предприятиями в различных районах страны и за ее пределами, с десятками тысяч занятых, с годовым объемом производства, исчисляемым миллиардами долларов, имеющая свои газеты, радиостанции и прочие средства СМИ, а также «своих» людей в конгрессе и правительстве. К крупнейшим военно-промышленным корпорациям США относятся: Lockheed Martin (авиастроение, авиакосмическая техника, судостроение), Boeing (авиатехника, ракетное вооружение, авиакосмическая техника), Raytheon (ракетно-космическая техника, электроника), Northrop Grumman (электроника, судостроение), General Dynamics (аэрокосмическая техника).

Высокий уровень концентрации и монополизации военного производства, а также высокая прочность позиций немногочисленных военно-промышленных монополий характерны и для Великобритании, Франции, Германии, Италии, Японии.

Крупнейшие мировые поставщики вооружений, безусловно, заинтересованы в систематическом увеличении военных заказов, обеспечивающих им гарантированный сбыт, ведь военный бизнес, как и любой другой, подчиняется действию основного экономического закона капитализма, который проявляется в стремлении получать максимальные прибыли. Не удивительно, что именно ВПК прежде всего выступает за усиление гонки вооружений, пытается доказать благотворность влияния военных расходов на развитие экономики. Кроем того, военно-промышленные монополии получают огромные прибыли не только от выполнения заказов для своих вооруженных сил, но и для торговли оружием на международном рынке, масштабы которой значительно возросли в XXI в.

Подчеркивая притягательность военнопромышленного бизнеса для частных предпринимателей, американские исследователи Г.Шиллер и Дж.Филлипс писали: «Рвение, с которым как многие из крупнейших промышленных корпораций, так и тысячи более мелких фирм стремятся заполучить военные контракты, свидетельствует о том, что прибыли от этого бизнеса, как правило, выше прибылей от внутреннего гражданского производства, несмотря на то, что заинтересованные в этом лица утверждают обратное» [1].

Однако специфические условия деятельности военно-промышленных корпораций накла- 
дывают свой отпечаток на применяемые ими конкретные методы получения этих прибылей. Помимо «официальной» прибыли (которая уже сама по себе может быть очень высокой), военнопромышленные корпорации получают от государства большое число финансовых и иных льгот, служащих источниками дополнительных, не учитываемых прибылей: щедрые авансовые платежи, возможность арендовать государственное оборудование на льготных условиях, бесплатное использование результатов научных исследований и опытно-конструкторских разработок, выполненных в государственных научноисследовательских центрах, возможность затягивать сроки поставок и получать компенсации перерасходов (нередко неоправданных), первоочередное снабжение дефицитными материалами и т.д. Военно-промышленные фирмы зачастую ухитряются включать в представляемые министерству обороны счета расходы на рекламу производимых ими систем оружия и даже на угощение и подарки «полезным» лицам.

Для увеличения своих доходов военнопромышленные корпорации используют и некоторые особенности современного производства, обусловленные научно-техническим прогрессом. Техническая сложность современных систем оружия и отдельных компонентов затрудняет установление цен на них, и военно-промышленные корпорации стремятся воспользоваться этим обстоятельством. Наличие нескольких «ярусов» субподрядчиков при производстве крупных систем оружия дает возможность строить «пирамиды прибылей», когда прибыль исчисляется по отношению не к фактическим расходам, понесенным генеральным подрядчиком или субподрядчиками верхних «ярусов», а к суммарным расходам всех нижних «ярусов» подрядчиков.

Выгода извлекается также из сложности и запутанности контрактных процедур, значительно возросшего объема технической документации и т.д. Получив контракт, военно-промышленные корпорации тут же нанимают опытнейших юристов, чтобы они «выжали» максимальные выгоды из условий контракта. Подрядчики завышают размеры компенсации за внесение заказчиком изменений в конструкцию.

Американский экономист Сеймур Мелман, исследовавший принципы функционирования ВПК США, в своих работах утверждал: «В отличие от гражданских фирм, которые традиционно стремятся свести к минимуму производственные издержки ради извлечения максимальной прибыли, фирмы на экономической орбите Пентагона стараются как можно больше завысить все издержки, а тем самым и субсидии, которые будут им выплачены. Такой подход ведет к постоянному повышению цен» [3].

Руководство американских военно-промышленных корпораций придает большое значение развитию тесных связей с конгрессменами и сенаторами. Ведь в соответствии с Конституцией США Конгресс утверждает военный бюджет и ассигнования на отдельные военно-технические программы, а также ратифицирует международные договоры. Основными формами связей военно-промышленных корпораций с Конгрессом являются: финансирование избирательных кампаний, угодных им кандидатов, деятельность военных лоббистов, предоставление подтасованной информации по военным и внешнеполитическим вопросам и др.

Американский исследователь Авраам Ярмолински по этому поводу писал: «В течение многих лет самые крупные контракты идут, как правило, в округи наиболее влиятельных членов комиссии по делам вооруженных сил, которые, в свою очередь, обычно голосуют за программу, предлагаемую Пентагоном» [3].

Крупные военно-промышленные корпорации также имеют в Вашингтоне специальные бюро, занимающиеся лоббизмом - «обработкой» членов комиссий по делам вооруженных сил Сената и палаты представителей и правительственных чиновников с целью склонить их на сторону «своей» корпорации.

Необходимо упомянуть и о таком явлении, как «вращающиеся двери». Так называют в США «обмен руководящими кадрами» между министерством обороны и военно-промышленными корпорациями. Он состоит в том, что военные промышленники получают крупные гражданские посты в Пентагоне, а генералы, адмиралы и старшие офицеры, обычно из числа ведавших закупками вооружения и военной техники, после ухода с военной службы занимают высокооплачиваемые должности в военно-промышленных корпорациях.

Явления, подобные «вращающимся дверям», существуют и в других странах. «Амакудари», то есть «сошедшие с небес»,- так называют в Японии генералов и старших офицеров, перешедших после увольнения с военной службы на ра- 
боту в военную промышленность.

В ВПК также, как правило, входит или непосредственно примыкает к ним большое число различных милитаристских организаций, среди которых выделяются три основные группы: ассоциации военных промышленников, профессиональные ассоциации кадровых и бывших военнослужащих, а также различные шовинистические организации. Крупные военно-промышленные корпорации, как правило, входят одновременно в несколько таких организаций. Финансируя эти организации, они стремятся полностью подчинить себе их деятельность. Все эти организации выступают за использование военной силы в международных отношениях, за раздувание военных бюджетов, за непрерывное наращивание военной мощи. Они активно ведут милитаристскую пропаганду и всячески препятствуют заключениям соглашений об ограничении стратегических вооружений. Такие организации издают огромное количество материалов о «потенциальной военной угрозе», финансируют создание провокационных фильмов. Особое значение ВПК придают установлению контроля над средствами массовой информации в целях раздувания милитаристской пропаганды, которая и служит обоснованием и оправданием наращивания военных расходов.

«Потенциальная военная угроза» служит стержнем милитаристской пропаганды, которая по самому своему существу является идеологической подготовкой новой войны, идеологическим компонентом гонки вооружений. Военнопромышленные корпорации, наживающиеся на разработке и производстве орудий уничтожения и потому кровно заинтересованные в раздувании военных бюджетов, взвинчивании «гонки вооружений», широко используют понятие «потенциальная военная угроза».

Еще в 50-х гг. один из активных творцов «хо- лодной войны» - Дж. Даллес, занимавший тогда пост государственного секретаря США, говорил: «Чтобы заставить страну нести бремя, с которым связано содержание мощных вооруженных сил, необходимо создать эмоциональную атмосферу, родственную психологической обстановке военного времени. Надо создать представление об угрозе извне» [2].

Отмечающееся в последние годы резкое возрастание роли ВПК обусловлено особым сочетанием политических, экономических и социальных факторов, воздействующих как на международную ситуацию, так и на внутриполитическое положение в отдельных странах, прежде всего в США и КНР, имеющих крупнейшие военные бюджеты в мире на сегодняшний день. Усиление влияния ВПК объясняется тем, что их деятельность соответствует общестратегическим, политическим и экономическим интересам этих стран.

Раздувание военных бюджетов - это предоставление в распоряжение военно-промышленных монополий огромных дополнительных ресурсов, что заметно укрепляет их экономические позиции, расширяет их возможность влиять на экономику. Даже сегодня, в условиях общего спада в мировой экономике, военная промышленность остается одной из немногих процветающих отраслей.

Усиливая гонку вооружений, в ходе которой одни системы стратегического оружия сменяются все более разрушительными, ВПК стремятся создать для себя поле гарантированных заказов и прибылей. Однако новый виток в гонке вооружений, расширение военно-технических программ неизбежно приведут к дальнейшему усилению милитаризации мирового хозяйства. Поэтому на сегодняшний день именно ВПК можно назвать одним из главных материальных носителей идей милитаризма, его воплощения в экономическом и политическом плане.

\section{Библиографический список}

1. Борисов В.В., Фарамазян Р. А. Милитаризация капиталистической экономики и ее социально-экономические последствия.-М.: Знание, 1983.-64 с. - (Новое в жизни, науке, технике. Сер. «Экономика»; № 2).

2. Волкогонов Д. А. Психологическая война.-М.: Прогресс, 1986. - 262 с.

3. Милитаризм: цифры и факты / [В.В.Борисов, В.П. Васютович, П.Л.Иванов и др.; Под общ. ред. Р.А.Фарамазяна].-М.: Политиздат, 1983.-255 с.

4. Eisenhower, D. D. Farewell Address (17 January 1961)// The Annals of America. - Vol. 18. 1961-1968: The Burdens of World Power.- Chicago: Encyclopaedia Britannica, 2003.-689 p. 